精度がある。

3）基板の絶緑抵抗は温度上昇处り劣化する。高温 度ではむしろ吸湿劣化以上の低下を示すので，装埴の使 用温度により基板の選択には十分注意を払うべきであ る.

終りに本研究にで指尊を戴いた東京工業大学斎藤教 授，岩倉教授および実験に協力くだされた実験室の諸君 に感謝いたします。

(昭 34-6-20 受理)
文 献

1) 小楖進一，本詰 $25,489(1957)$.

2) 小版進一, 本誌 26, 556 (1958).

3）小概進一，本誌 27，635 (1959)。

4）たとえば D.H. Andrews, J. Johnstone, J. Am. Chem. Soc. 46, 640 (1924).

5）たとえば電気通信学会糄, 通信工学ハンドブック（昭32）丸善.

6) 河合鳞次郎, 香田武夫，電学誌論文集 5, 131 (1944).

7）たとえば Mott, Gurney，イオン結晶論（昭21）劣善.

8）小楖進一, 本誌 28, 198 (1960).

\title{
解コウ塔における水素ガスの効果*
}

\section{Effect of Hydrogen Gas on Amalgam Decomposition Tower}

\author{
日 根文男**, 吉 沢 四 郎** \\ Fumio Hine, Shiro Yoshizawa
}

\section{緒論}

解コウ時に発生した水素ガスを速やが除去すること が解コウ操作の要領の一つとされているが，それ亿対す る詳しい理論的赛付はいまだ報告されていない。こてで はこの水素がスがどのように解コウ反応の進行を奶げる かてついて考觉よう。

解コウ塔住充てん材としての解コウ粒を塔内に充てん し，塔頂加アマルガムを流下させ，このアマルガムは 解コウ粒と塔の各部にて接触し, 敌部電池を形成して解 コウ反応という一種の電気化学反态を行う．したがって 解コウ塔は見方によって縌に長い電解りウの一つの変形 とも考觉られる。ただ，塔頂と塔底ではアマルガムの濃 度が著しく異なり，また場合によってはカせイソーダの 濃度も異なるから当然各々の部分での起電力が違った值 尼とが、下部で発生したガスがしだいに上周に滞積し てゆくなどという現象は正しく水電解りウなどと同様な 内容のものである ${ }^{1)}$ 。このように考えると，発生した水 素ガスの効果として，すでに詳しく論じたように，水素 電極としての解コウ粒の表面认対するしゃへい作用と, カセイソーダ液中への分散による液の才一ム損の增大上 いう2つを挙げることができる゙。

\section{1. 解コウ粒表面のしゃへい作用}

すでに詳しく論せたように解コウ粒の有效面積は水銀 流量によって著しく影留される3，その最大値は水銀流量 $300 \sim 400 \mathrm{~kg}-\mathrm{mol} / \mathrm{h} / \mathrm{m}^{2}$ において，解コウ粒の真の表面 積の大体 $60 \%$ 程度である. ての測定値はかなりの幅を もった値ではあるが，アマルガムの浱度にはそれ程大き

\footnotetext{
* 解コウの工学的研究 (第8 報) Studies on Amalgam Decompasition of Alkaline Industry (Part 8)

** 京都大学工学部工業化学数室 (京都市左京区吉田本町)
}

く影響されない模様である。これは水銀流量の多少によ って局部電池形成の機会が規定され，それか解コウ粒の 面積の有效率を左右するからである。ささらに，相手極が 遠くへだたる一般の電解ソウと仗異なり，解コウ塔では 解コウ粒とアマルガム粒とが接触している境界面附近で 大きな局部電流が流れ発生した水素ガスは解コウ粒の全 面に抎がってその表面を蔽うが，アマルガムとの接触部 分ではその幾何形状から水素ガスによって著しく局部電 流の通路をさ元ざられるようなととはない考劣られ る、すなわち，見かけ上，水素ガスが解コウ粒の表面を 大きく蔽うけれども，陰極として実際上最も有效な接触 界面附近はその水素過電仕を大幅に変動させる程妨害し ない.

\section{2. オーム损の増大}

発生した水素ガスがどれはど液中に滞留しているかを 知るために、つぎのような実験を行なった。すなわち図 1 亿示すように, 直 径 $95 \mathrm{~mm} \phi$ のガう スの塔に $10 \mathrm{~mm} \phi$ の球状解コウ粒を $0.97 l$, 高さにし て $200 \mathrm{~mm}$ 充てん し,カセイソーダ 液を入れて, この 荅の下部から水素

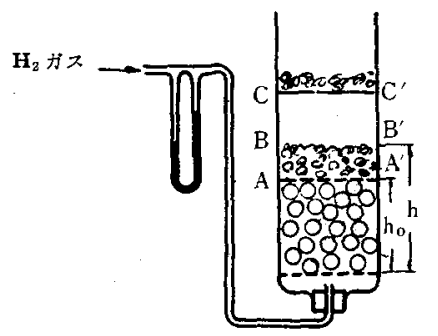

图1解コウ塔 ガスを吹き込んだ・そうすれば液は激しい泡立ち起す が，その上部が，ちょうど充てん層の上面, 図では $\mathrm{BB}^{\prime}$ の位置にくるようにし，つぎに水素がスの吹込み势止め た場合の液面, 図では $\mathrm{AA}^{\prime}$ の高さ読み取った。この

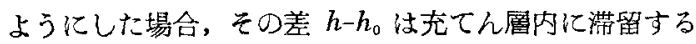
水素ガス量化当る。この値仗当然，カセイソーダ液の濃 


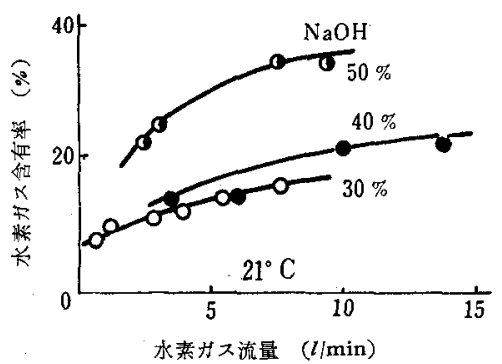

図 2 水素ガス流量による液中会有量の变化

度や水素ガスの流量によって変るもので，図2はるの結 果を示す，すなわち，縦軸には水素ガスの含有率 $(h-$ $\left.h_{0}\right) / h$ の值を採り・横軸には水素ガス流量を採ってある。 との結果から，50\%力セイソーダ液の場合には水素がス は液の約 30〜40\% を占めることがわかる。いま水銀流 量尼 $330 \mathrm{~kg}-\mathrm{mol} / \mathrm{h} / \mathrm{m}^{2}$ ，アマルガム濃度 $0.2 \%$ とし，て れが完全にての塔内で解コウしたとすれば，水素発生量 は約 $8.5 \mathrm{l} / \mathrm{min}$ となる.したがって，図 2 の実験範囲は かなり広いことがわかる，液温が上ると液の粘度が低く なるが，水素ガスの容積が鼔張して，液中の含有率はそ れ程変らない。

このように液中にガスが分散して含有されると，液の 見掛の需導度は小さくなる2。これについてはすでに詳 説したが，Hantge らの研究結果を援用すると $30 \sim 40 \%$ のガス含有に対して，抵抗增大が 1.8 2.2 倍となり したがって $x$ としては真の電導度に0.55 0.45 を乗し た值を採用しなければならない，とのととは $K$ や $[H$. T.U.]に大きく影響するはずである ${ }^{5}$.

\section{3. 総括物質移動係数に及ほすす水素ガスの効果}

そこでこの事実を明 らかにするために，図 3 に示した解コウ塔の 底部から便宜上窒素ガ スを通じて，その結果 Kがどのように変るか を調べた。実験条件は つぎのとおりである。

$$
\begin{array}{ll}
\text { カセプソーダ } & 40 \% \\
\text { 温废 } & 50^{\circ} \mathrm{C}
\end{array}
$$

解コウ粒径

$15 \mathrm{~mm} \phi$

ガス流量 $2.1 \mathrm{l} / \mathrm{min}$ 得た結果注，図 4 亿示 す上うに，その効果は それ程大きくはないが $K$ が約 $10 \%$ 前後小さ くなることを知った， これは一般のガスの発

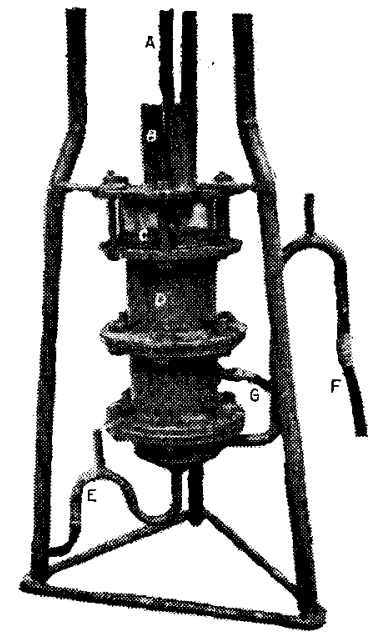

A：アマルガムパイプ B：水菜パイフ C : 分散盤 D：充てん部 $\mathbf{E}:$ 水銀㞔りパイプ $\mathbf{F} ：$ 力七インー

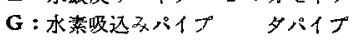
因3 解 コウ塔

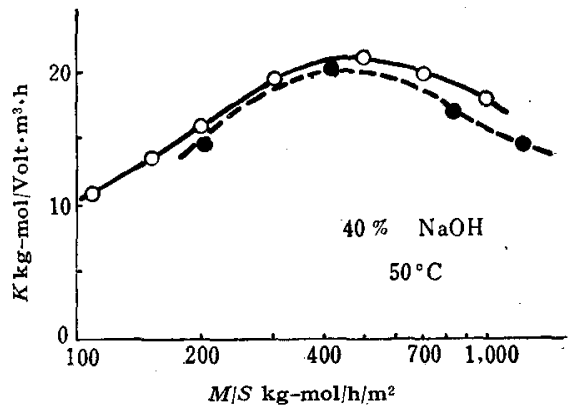

一。一ー゙スを通さない場合，ーーーーーガスを通した場

合 $(2.1 l / \mathrm{min})$

図 4 総括物質移動係数

生する䉓解ソウとは異なり，解コウ塔に执いては陽極で あるアマルガムと，陰極である解コウ粒とが非常に接近 しており，かつそのように接近した部分か電極として最 も有効に働くために，溶液中に分散したガス渞に電流の 通路がそれ程大きく妨げられるというようなととがない もの之考光られる、設計に際してはこれを加味して荅高 を計算值より1割程度高くすることが望ましい。

\section{4. 泡切れの状態}

水素ガスの挙動関してもう一つの重要なととがらは 泡切れの難易状態である．充てん層の上部すれすれに液 面を下げて操業すれば，充てん層方汁分使用されないで 不利なととは容易にわかるので，それではどれだけ液面 を上げなければならないかを知るために図 1 の菨置を用 い， $\mathrm{CC}^{\prime}$ のところまで50\% カセイソー名液を入れて水 素ガスを送った。泡は約 $6 \mathrm{~cm}$ 生じ， BC 間には細かけ 気泡が分散していたが，液面上部で起る泡切れと釣合っ て，割合円滑に上昇している有様か認められた。また， 充てん風でのガスの上昇手予想したより容易に行われて いるようであった. そうして，ての時の充てん層でのガ 又分散の状熊法，液面を $\mathrm{AA}^{\prime}$ や $\mathrm{BB}^{\prime}$ まで下げて場合 とは相当違うように見受けられ，液面での泡切れ状態が 允てん風のガス分散状態響くことがわかった。したが って，てのととから液面社少なくとも充てん層上り10〜 $15 \mathrm{~cm}$ 高く保つととが必要であろうと考光る。

\section{結論}

1. 解コウによって発生した水素ガスが，あるいは解 コウ粒表面を蔽い，あるいはカセイソー多液中に分散す ることによって解コウ塔の物質移動係数を小さくし，塔 容積に影響すると考えられるので, 理論的, 実験的に検 討した。

2. カゼイソーダおよびアマルガム濃度を変化させて 解コウ塔を運転し，あるい溚下部から水素ガスを相当: 多量吹込んでも総括物兵移動係数はあまり変らない。こ の事実は一般のガス発生電解ソウでの発生ガスの効果と 
は多分に様子が異なる。これは電場の幾何形状の違いに よるものと考元られる。

3. 総括物質移動係数は約 $10 \%$ 程度减少するとして 設計際しては所要塔高を10\%高く採九ばよい。

4. 発生する水素ガスのもう一つの挙動として注目し なければならないてとに液面での泡切れの良否であるが 泡立ちは $10 \mathrm{~cm}$ に及ばないととが実験的にわかった。し たがって実際には液のレベルを充てん周上部より $10 \mathrm{~cm}$ 高く保てば十分である。

なお, 本研究にいろいろの便宜を与えられた大阪曹達
株式会社横田範之氏，および実験を分担された星野稔 (京大)，久代二郎 (大阪曹達) 両君に謝意を表する.

昭 34-6-27 受理)

文 献

1）岡田辰三，吉沢四郎，日根文男，竹原善一郎，山下正通，本誌 28 205 (1960).

2）日根文男，吉沢四郎，岡田辰三，本誌 24，370 (1956).

3）日根文男，吉沢四郎，本詰 27，475 (1959).

4) Hantge, Engelhardt, Handbuch der Technischen Elektrochemie II, Bd. 1, T1 B 8, 10 (1933).

5) 日根文男, 吉沢四郎, 本誌 2B，50 (1960).

書評

\section{電熱化学 エ 業 工業化学全费 16}

武井 武, 小島 武, 友成忠雄共著

A 5 判 本文 267 ページ 定值 380 円

発行所 日刊工業新聞社

電熱化学工業は日本の電気化学工業のうちで最む多量の電力 を消費する重要産業であるにすかかわらず，電気化学界では近 頃この方面の研究の発表や著述分少なくて，一抹の淋しさを感 していた㱡沉, 今度「電熱化学工業」が工業化学全書の一環 として，日刊工業新聞社から発刊せられたことは，この路を生 命としているわれわれにとって非常なよろこびである。

著者蛙武井 武 (慶応大学), 小島 武 (東京工業大学), 友成 忠雄（横浜国立大学）の三教授であって、いずれもこの道の一 流大家であり，また，当協会の役員として，あるい怙怵や研 究調査の尃門要員または委員長として，多年なじみの深い方队 であるから，今更紹介の必要もないと思う。また劣の内容につ いても無条件で推奖したい，本書の内容路基檚編と応用編にわ 玑れているが，前者を武井博士が，また，後者のうち金属部門

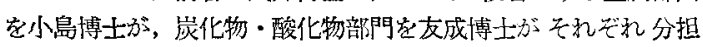
執筆されている。

基礎編は総論，製鍊，電気炉からなり，製錬の章に泣総説， スラグとその性質, 融解金属, 製鍊の化学变化について, また 電気炬の章汇性炉の型式，構造，熱収支，電気的特性，諸元に ついて記載されている。

応用編のうち，金属の章では電気製鉄，電気製銅，フェロオ ロイ( $\mathrm{Fe}-\mathrm{Si}, \mathrm{Ca}-\mathrm{Si}, \mathrm{Fe}-\mathrm{Mn}$, スピーダル, $\mathrm{Si}-\mathrm{Mn}, \mathrm{Mn}, \mathrm{Fe}-$ $\mathrm{Cr}, \mathrm{Fe}-\mathrm{W}, \mathrm{Fe}-\mathrm{Mo}, \mathrm{Fe}-\mathrm{P}$ ，その他）の製造它，また炭化物・酸 化物の章で注, 黒鉛, 二硫化炭素, 炭化ケイ素,カーバイドおよ
び石灰窒素, リンおよびリン酸, フランダムのほか, 各種の崕化 物，木ウ化物，ケイ化物，窒化物についてまとめて記述されてい る. との部門のうち, 溶成りン肥や融解耐火物については記述 が見当らなかったが，紙数の都合で省略されたものであろう．

私の感した本書の大きな特色は，基礎編・応用編ともに，そ の中に一般ならびに各種の高温化学変化についての新しい理諭 や反応機構が記述せられ，特にスラグについては從来未開であ ったこの分野に, 最近ひらけた学説や研究結果をよくまとめて 解説せられている点などで，これは金属製鍊の理論とともに読 者を大いに机し党。その眼を開いてくれることであるう。ま， 全般炕たって各種の熱力学的数值や状熊图加十分汇盛られ， 内外の文献やデータがかなり取入れられ，これらがよくダイジ ェストされていること，さらに大切岁ことはこれらの中に三博 士の業績が多数入っている点も特記したい。

また，実除面でも，各種の電柿について図示するとともに， 電気的な面や棈造の面, 操業法, 熱収支などにわたって, キ一 ポイントがょく示されているし，製造面でも，原料，敝造法， 原単立, フローシート, 製品規格, 分析, 統計乹よび技術の進歩 などについて，必要と思われるデータがかなり詳細比郡述され ており，有用な新しい写真や図表なども多数揭載されていて， 著者の苦心がしのばれる。

著者の序文によると, 本書はもと大学工学部の学生向として 記述された由であるが，緍数の閶倸から内容恀簡明ではあるが 豊富であり, 高度であるから, 電熱化学工業関係の尃門技術者

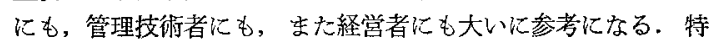
に現場の人々にはぜひ一読の上，机上に常置せられる上うおす すめしたい.

私どむは本書の刊行を大いに感禹しているが，ロー害得てシ ヨクを望むなら代，本書を更に大成せられて，もっと詳細な大 成判とし，世界有数の生産国たるかが国電熱化学工業の技術の 一詹の進展の原動力としていただきたいことである。

(評者, 電気化学工業(株) 青野武雄) 